\title{
Autocrine signalling as cause of sensitized cAMP formation
}

\author{
Christian Nanoff*, Qiong Yang, Edin Ibrišimović \\ From 17th Scientific Symposium of the Austrian Pharmacological Society (APHAR). Joint meeting with the \\ Hungarian Society of Experimental and Clinical Pharmacology (MFT) \\ Innsbruck, Austria. 29-30 September 2011
}

\section{Background}

Cyclic adenosine monophosphate (cAMP) is a second messenger essential for neural functions. The propensity of a nerve cell to mount a cAMP response may be conditional, e.g. depending on a preceding exposure to stimuli (as in long term potentiation).

\section{Methods}

We measured cAMP formation in SH-SY5Y neuroblastoma cells at various stages of differentiation to a neuronal phenotype. We analyzed expression pattern of enzymes involved in regulated cAMP production, differentiation markers and protein composition of culture supernatant.

\section{Results}

SH-SY5Y cells (a model nerve cell) required differentiation to produce cAMP in substantial amounts; in undifferentiated proliferating cells, forskolin or activation of $\mathrm{G}_{\mathrm{s}}$-coupled receptors barely stimulated cAMP formation. A cell-autonomous process induced sensitization. The process relied on an autocrine factor, which we identified as Dickkopf1 protein. Serum protein quenched the activity of Dickkopf1; conversely, serum deprivation allowed for sensitization to unfold. The effect of Dickkopf1 was mediated by a high-affinity receptor activated at concentrations of $\leq 1 \mathrm{nM}$. In accordance with its cognate function as Wnt antagonist, sensitization was a consequence of suppressing the canonical Wnt signaling pathway; the inhibitors of glycogen-synthase kinase- $3 \beta$, lithium chloride and, in addition, valproic acid mimicked Wnt signals and diminished the extent of sensitized cAMP formation. We found that in differentiated cells, expression of the

\footnotetext{
* Correspondence: christian.nanoff@meduniwien.ac.at Institute of Pharmacology, Center of Physiology and Pharmacology, Medical University of Vienna, 1090 Vienna, Austria
}

$\alpha$-subunit of $G_{s}\left(G \alpha_{s}\right)$ increased due to activation of the GNAS gene. Although sufficient to support $\mathrm{G}_{\mathrm{s}}$-coupling of the $A_{2 A}$ adenosine receptor, increased $G \alpha_{s}$ alone failed to enhance receptor-stimulated cAMP formation. We infer that sensitized cAMP formation reflected increased responsiveness of the catalyst, adenylyl cyclase, to stimuli.

\section{Conclusions}

SH-SY5Y provide for a nerve cell model to study the effect of Wnt signaling on regulated cAMP formation. Our data suggest that mood stabilizing agents act by reducing the ability of nerve cells to produce cAMP.

Published: 5 September 2011

doi:10.1186/1471-2210-11-S2-A37

Cite this article as: Nanoff et al:: Autocrine signalling as cause of sensitized CAMP formation. BMC Pharmacology 2011 11(Suppl 2):A37.
Submit your next manuscript to BioMed Central and take full advantage of:

- Convenient online submission

- Thorough peer review

- No space constraints or color figure charges

- Immediate publication on acceptance

- Inclusion in PubMed, CAS, Scopus and Google Scholar

- Research which is freely available for redistribution
() Biomed Central

\section{Biomed Central}

